\title{
Näin toimii kehittämishanke Case: Peltoenergia Kainuussa -hanke
}

\author{
Elina Virkkunen ${ }^{1)}$ ja Jari Korhonen ${ }^{2)}$ \\ 1) MTT Sotkamo, Kipinäntie 16, 88600 Sotkamo, elina.virkkunen@mtt.fi \\ 2) MTT Sotkamo (Nykyinen osoite: Sotkamon kunta, Markkinatie 1,88600 Sotkamo), \\ jari.korhonen@sotkamo.fi
}

\section{Tiivistelmä}

Kehittämishanke on yksi keino viedä tutkimustietoa suoraan sitä hyödyntäville viljelijöille. Peltoenergia Kainuussa -hankkeen tarkoituksena on ollut edistää ruokohelven ja muun peltoenergian tuotantoa Kainuun alueella. Tiloja on aktivoitu tiedottamalla peltoenergian ja uuden viljelykasvin tuotantomahdollisuuksista. Hanke toteutettiin vuosina 2004-2007.

Hankkeen aikana järjestettiin pelto- ja bioenergiaan liittyviä koulutustilaisuuksia, info-päiviä, pellonpiennarpäiviä ja opintoretkiä. Peltoenergiasta kiinnostuneille viljelijöille annettiin tietoa päätöksenteon tueksi heidän miettiessään oman tilansa tuotantomahdollisuuksia.

Tilaisuuksiin osallistui yhteensä yli 120 viljelijää. Tämä on noin $12 \%$ Kainuun viljelijöistä. Kouluttajina toimivat sekä alan toimijat maakunnassa että kauempaa tulleet asiantuntijat. Erityinen huomio kiinnitettiin ruokohelven viljelyn haasteellisiin kohtiin kuten perustamiseen, rikkakasvien torjuntaan ja korjuuseen. Tällöin viljelijä välttyy tekemästä tiedon puutteesta aiheutuvia virheitä uuden viljelykasvin tuotannossa.

Ruokohelven viljelylle laadittiin hankkeessa kannattavuuslaskelmamalli, jota viljelijät voivat soveltaa tilalleen. Viljelijöille pyrittiin antamaan kuva myös ruokohelven polttoainekäytöstä. Paikallisen konepajan kanssa kehitettiin yhteistyössä paalimurskain, jolla voidaan silputa pyöröpaalit esimerkiksi turvesuolla. Urakoitsijoiden yhteystiedot ja taksat koottiin listalle viljelijöitä varten. Urakoitsijat kutsuttiin myös korjuuta käsittelevään koulutukseen.

Hankkeen aikana aloitettiin ruokohelven viljely yksityistiloilla Kainuussa. Ensimmäiset viljelijät kylvivät ruokohelpeä keväällä 2005. Nämä yrittäjät korjasivat satoa keväällä 2007. Vuonna 2007 viljelysopimuksia oli tehty 22. Viljelypinta-ala oli yhteensä 268 hehtaaria.

Peltoenergian merkitys Kainuun voima- ja polttolaitoksilla on kokonaisuuden kannalta marginaalinen. Sillä on suurempi merkitys tilakohtaisesti uutena tuotantovaihtoehtona. Maakunnan pohjoisesta sijainnista johtuen etanoli ja biodiesel eivät ole Kainuussa varteenotettavia peltoenergian muotoja. Ruokohelpi puolestaan kasvaa Kainuussa yhtä hyvin kuin Etelä-Suomessa. Energiapajulla olisi voimalaitoksissa suuri käyttöpotentiaali, mutta sitä ei Kainuussa viljellä lainkaan.

Hankkeen edetessä tiloilla heräsi kiinnostus biokaasun tuotantoon. Pellolta voi saada energiaa myös mädättämällä biomassaa reaktorissa. Osa koulutuspäivistä, opintoretkistä ja neuvonnasta käsitteli biokaasun tuotannon mahdollisuuksia maatiloilla.

\section{Avainsanat}

ruokohelpi, Phalaris arundinacea L., peltoenergia, kehittämishanke 


\section{Johdanto}

Suurin bioenergiapotentiaali Suomessa ja erityisesti Kainuussa on metsäenergiassa. Kainuun voima- ja polttolaitokset käyttävät polttoaineenaan pääosin puuta ja/tai turvetta. Sen lisäksi Kainuussakin voidaan tuottaa peltoenergiaa, jossa on merkittävä käyttämätön bioenergiamahdollisuus (Karjalainen 2006).

Ruokohelven (Phalaris arundinacea L.) viljely soveltuu hyvin pohjoisille alueille. Helpi tuleentuu myöhään syksyllä ja sato korjataan seuraavana keväänä. Ruokohelven kuiva-ainesato on noin $6000 \mathrm{~kg}$. Talven jälkeen kasvimassan polttoaineominaisuudet ovat hyvät, ja se soveltuu seospolttoon puun ja turpeen kanssa (Pahkala ym. 2005). Viljely on lähes kokonaan sopimusviljelyä, ja sato käytetään suurissa voimalaitoksissa. Kainuussa suurin käyttäjä on Kainuun Voima Oy:n voimalaitos Kajaanissa.

Peltoenergian jalostaminen biodieseliksi ja etanoliksi ei sovellu hyvin Kainuuseen. Alue on liian pohjoisessa laajempaa öljykasvien viljelyä ajatellen. Myöskään oljen käyttö energiaksi ei tule olemaan merkittävää. Viljanviljely on vähäistä, eivätkä korjuuolosuhteet salli oljen talteenottoa joka vuosi.

Vihermassan mädättäminen biokaasureaktorissa on mielenkiintoinen mahdollisuus tuottaa pellolla energiaa. Tällöin tila voi hyödyntää syntyneen energian itse ja saavuttaa omavaraisuuden lämmön ja/tai sähkön suhteen. Energiasta voi tulla tilalle myös myyntituote. Samalla tila saa mädätysjätteestä käyttökelpoista lannoitetta.

MTT Sotkamo toteutti kolmivuotisen kehittämishankkeen Peltoenergia Kainuussa vuosina 2004-2007. Projektin päätavoite oli edistää peltoenergian, erityisesti ruokohelven tuotantoa Kainuun alueella. Hankkeen kokonaisbudjetti oli 135000 euroa. Hanke työllisti yhden henkilön kokopäivätoimisesti.

Projektin päärahoittajia olivat EU (EMOTR = Euroopan maatalouden ohjausrahasto) ja Suomen valtio, yhteensä $80 \%$ kustannuksista. Projektin muut rahoittajat olivat Kainuun kunnat $10 \%$ :n osuudella sekä yksityisrahoittajat $10 \%$ :n osuudella. Yksityisrahoittajia olivat Vapo Oy, Kemira GrowHow Oyj ja Boreal Kasvinjalostus, MTK-Kainuu ry ja paikalliset viljelijät.

Vapo Oy viljelee ruokohelpeä turvetuotannosta poistetuilla soilla, ja tekee sopimuksia myös yksityisviljelijöiden kanssa. Vapo toimii ensijalostajana, joka ostaa korjatun sadon ja käyttää sen yhtiön omissa voimalaitoksissa tai myy sen muille käyttäjille. Sopimuksen teko edellyttää alle 100 km:n matkaa käyttöpaikalle.

\section{Tavoitteet ja toimenpiteet}

Hankkeen tavoite oli aktivoida peltoenergiatuotantoa Kainuussa. Tarkoituksena on ollut löytää uusi ja kannattava tuotantovaihtoehto maatiloille. Hankkeella tavoiteltiin peltoenergiantuotannon käynnistymisen myötä edullisia vaikutuksia ympäristöön.

Rahoittaja on nähnyt tarpeelliseksi peltoenergiatuotantoa muun muassa seuraavista syistä: Peltoenergiakasvien viljely monipuolistaa tilojen tuotantomahdollisuuksia. Peltobiomassan polttaminen vähentää voimaloiden $\mathrm{CO}^{2}$-päästöjä ja parantaa siten ilmaston tilaa. Peltoenergia monipuolistaa energialähteiden valikoimaa ja lisää paikallisten raaka-aineiden käyttöä. Samalla saadaan kokemusta uusiutuvan energian tuotannosta ja uudesta polttoaineesta. Ruokohelpi viljelykasvina parantaa vesistöjen tilaa vähentämällä ravinnehuuhtoumia. Maaperän tila paranee, koska pitkäaikaisten nurmien viljely lisääntyy. Peltoenergia turvaa osaltaan avoimen ja viljellyn peltomaiseman säilymistä ja tarjoaa suojaa riistaeläimille.

Sekä suomalaisten että ulkomaisten tutkimusten tuloksia tuotiin käytäntöön ja suoraan viljelijöiden hyödynnettäviksi. Tämä toteutettiin järjestämällä koulutustapahtumia, info-päiviä, pellonpiennarpäiviä ja opintomatkoja sekä kirjoittamalla aiheesta artikkeleita yleis- ja ammattilehtiin. Viljelijät saivat myös tilakohtaista neuvontaa. Tiloille tehtiin viljelysuunnitelmia sekä neuvontakäyntejä. Viljelijöiden kanssa pohdittiin muun muassa perustamisen onnistumista ja rikkaruohontorjuntaa.

Kolmen vuoden aikana järjestettiin 17 koulutuspäivää ja 8 opintomatkaa. Koulutuspäivien aiheina olivat ruokohelven viljelytekniikka ja korjuuhaasteet, kannattavuus sekä tuki- ja sopimusasiat. Matkoilla tutustuttiin ruokohelpiviljelmiin, korjuutekniikkaan ja voimalaitoksiin. Ruokohelpi on monivuotinen kasvi, jonka perustamiseen kannattaa perehtyä. Perustamisvuonna tehdyt virheet ja laiminlyönnit haittaavat sadonkorjuuta koko viljelyajan, joka voi olla yli kymmenen vuotta. Hankkeen 
tavoitteena oli helpottaa viljelyn aloittamista. Viljelijöiden ei tarvitse hankkia tietoa uudesta kasvista kokeilemalla ja tekemällä virheitä.

Viljelijäkoulutuksessa on kiinnitetty erityistä huomiota korjuutekniikkaan. Korjuutappiot voivat olla $40 \%$ kuiva-ainesadosta (Pahkala ym. 2005). Hanke on osallistunut MTT Ruukin järjestämiin tutkimuksiin korjuutappioiden minimoimisesta. Korjuututkimusten uusin tieto ja kokemukset saatiin viljelijöiden käyttöön samana vuonna. Ruokohelven viljelylle laadittiin hankkeessa kannattavuuslaskelmamalli, jota viljelijät voivat soveltaa tilalleen. Koulutuksessa perehdyttiin myös sadon laatutekijöihin ja niiden vaikutukseen polttoainekäytössä.

Hankkeen avulla edistettiin yhteistyötä ruokohelven tuottajien ja käyttäjien välillä. Viljelijöitä kutsuttiin tilaisuuksiin lehti-ilmoituksilla ja tilakohtaisilla kirjeillä. Urakoitsijoiden yhteystiedot ja taksat koottiin listalle viljelijöitä varten. Urakoitsijat kutsuttiin korjuuta käsittelevään koulutukseen. Paikallisen konepajan kanssa tehtiin laitekehitystä.

Koulutuspäivillä ja opintomatkoilla tutustuttiin myös energian tuotantoon biokaasun avulla. Kiinnostus siihen oli lähtöisin viljelijöiltä itseltään, ja aihe liitettiin hankkeeseen myöhemmin. Muutamille tiloille tehtiin myös alustava suunnitelma biokaasulaitoksesta.

\section{Tulokset ja johtopäätökset}

Kainuulaiset viljelijät ovat olleet kiinnostuneita ruokohelvestä uutena viljelykasvina. Yhteensä yli 200 henkilöä osallistui koulutuspäiviin tai muihin hankkeen tapahtumiin. Heistä yli 120 oli viljelijöitä. Tämä on noin 12 prosenttia Kainuun viljelijöistä. Peltoenergiasta tiedotettiin myös kirjoittamalla lehtiartikkeleita ja kutsumalla toimittajia hankkeen tilaisuuksiin. Artikkeleita ilmestyi hankkeen aikana yhteensä $10 \mathrm{kpl}$. Muuta materiaalia olivat luentomonisteet, hanke- ja matkaraportit sekä maatiloille tarkoitettu infopaketti biokaasuntuotannosta. Hankkeelle laadittiin omat nettisivut MTT:n sivujen alle.

Ensimmäiset viljelijät kylvivät ruokohelpeä keväällä 2005. Vuonna 2007 viljelysopimuksia on tehty 22. Viljelypinta-ala on yhteensä 268 hehtaaria (Kainuun TE-keskus 2007). Vapo Oy:llä on lisäksi viljelyksiä Kainuun entisillä turvesoilla noin 300 hehtaarin alalla. Käytetyt lajikkeet ovat Palaton ja Chiefton. Koko maassa kasvaa ruokohelpeä noin 20000 hehtaarilla.

Ruokohelven viljely on tuonut tiloille uuden tuotantomahdollisuuden. Kasvi kiinnostaa osaaikaviljelijöitä, koska perustamisvuoden jälkeen työnmenekki on pieni. Muutamille lypsykarjasta luopuville ja eläkkeelle siirtyville viljelijöille ruokohelpi on ollut sopiva tuotantomuoto. Ruokohelpi viljelykasvina antaa työtä myös paikallisille urakoitsijoille ja koneyrittäjille. Voimalaitoksille ruokohelpi on paikallinen ja hiilidioksidineutraali biopolttoaine. Sen käyttö tukee EU:n ja Suomen tavoitteita biopolttoaineiden käytössä. Ruokohelven tuotantoketju on hankkeen aikana saatu käyntiin.

Projektin aikana kehitettiin paalisilppuri yhteistyössä sotkamolaisen Suokone Oy:n kanssa. Pyöröpaalit voidaan sen avulla murskata esimerkiksi turvesuolla. Silppu kuljetetaan turpeen seassa polttolaitokselle. Tämä ei lisää kuljetuskustannuksia, sillä kantavuusrajoituksen vuoksi turverekkaan jää tyhjää tilaa. Tämä voidaan täyttää kevyellä helvellä. Paalien murskausta kokeiltiin isolla murskaimella myös Kainuun Voima Oy:n polttoainekentällä, ja sen todettiin onnistuvan hyvin.

Ruokohelven kuljetus on taloudellisesti tehotonta, koska helven energiatiheys on pieni. Yhden megawattitunnin tuottaminen vaatii yli kolme irtokuutiota ruokohelpeä. Tämä on kolme kertaa jyrsinturpeen vaatima tilavuus (Itä-Suomen Energiatoimisto 2005). Kainuussa viljelijät korjaavat helpisadon pyöröpaaleihin, joiden tiheys ei ole kyllin hyvä. Kanttipaalaimia ei vielä ole maakunnassa käytettävissä. Kuljetuksen suunnittelussa on edelleen haasteita. Myös ruokohelven mahdollinen leviäminen viljelmien ulkopuolelle sekä kasvin allergisoiva vaikutus kaipaavat lisäselvitystä. Uudet peltoenergiakasvit kiinnostavat viljelijöitä, ja ne on tarpeen ottaa mukaan selvityksiin.

Kainuussa on peltoa noin 30000 hehtaaria. Siitä noin 20000 hehtaaria on nurmea. Itä-Suomen peltoenergiaohjelman mukaan peltoenergian viljelyyn on Kainuussa käytettävissä 26600 hehtaaria. Suurin osa tästä on suoalueita, jotka eivät tällä hetkellä ole viljelykäytössä (Itä-Suomen Energiatoimisto 2005). 


\section{Kirjallisuus}

Itä-Suomen Energiatoimisto 2005. Itä-Suomen peltoenergiaohjelma vuoteen 2010. Itä-Suomen Energiatoimiston julkaisu 1/05. ISBN 952-5093-42-5.

Kainuun TE-keskus, maaseutuosasto. 2007.

Karjalainen, T. 2006. Kainuun bioenergiaohjelma 2006-2010.Oulun yliopisto, Kajaanin kehittämiskeskus. $52 \mathrm{~s}$.

Pahkala, K., Isolahti, M., Partala, A., Suokannas, A., Kirkkari, A-M., Peltonen, M., Sahramaa, M., Lindh, T., Paappanen, T., Kallio, E. \& Flyktman, M. 2005. Ruokohelven viljely ja korjuu energian tuotantoa varten. 2. korjattu painos. $31 \mathrm{~s}$. MTT Jokioinen. 